\title{
LOS RETOS DE LA PRODUCCION DE ANONACEAS EN MEXICO: PRODUCCION Y MERCADEO ${ }^{1}$
}

\author{
SALAS PRAIZ JOEL SALOMÓN²
}

RESUMEN - Analizando los retos actuales del Mundo de las Anonáceas en México, debemos tomar en cuenta todos los participantes, desde el productor, pasando por los mercados de destino y hasta el consumidor final. En un ambiente agroalimentario globalizado y cada vez más competitivo, los negocios que se adaptan para satisfacer las necesidades de los consumidores son los únicos que sobrevivirán y crecerán. La Cooperación Inter-Empresarial, denominada por algunos "Empresa-Red"; para explotar conjuntamente las ventajas de la gran empresa (consorcio) y de la pequeña empresa (rapidez), es el primer gran reto. Un segundo reto lo integran los factores que impulsan el mercado: La Seguridad Alimentaria, La calidad del producto, La Innovación, La disminución de Costos, y El Desarrollo de Nuevos Mercados. Un tercer reto es La adaptación competitiva de las anonáceas al cambio climático. Encontrar microorganismos eficientes de control biológico para proteger alimentos, resulta un cuarto reto y una alternativa prometedora para el control de organismos indeseables. Posicionar a las Anonáceas como la Fruta Emblemática de América Latina en los Mercados Internacionales operando una Cadena de Valor Continental, y Converger con todos los actores continentales en este gran esfuerzo que impone la dinámica mundial; es sin duda, el Gran Reto y nuestra invitación, para asumirlo, en este memorable Congreso Internacional. Así como, la Integración del Ecosistema Continental de Innovación para el Desarrollo Sustentable de las Anonáceas.

Términos para Indexación: Annona muricata, Empresa Red, Cadena de Valor, Factores Impulsores del Mercado, Cambio Climático, Huella de Carbono.

\section{THE CHALLENGE OF ANNONACEUS PRODUCTION IN MÉXICO: PRODUCTION AND MARKETING}

\begin{abstract}
By analyzing the current Annonaceae's world challenges in Mexico, we consider all parties, from the producer, the target markets and all the way up to final consumer. In a globalized agribusiness environment and increasingly competitive, businesses that cater to the needs of consumers are the only ones that will survive and grow. The Inter-Entrepreneurial Cooperation, called by some "Network-Company", to jointly exploit the advantages of large companies (Consortia) and small business (quickness), is the first major challenge. A second challenge is composed of the factors driving the market: Food Safety, Product Quality, Innovation, Lower Costs, and Developing New Markets. A third challenge is adapting Competitive Annonaceae to climate changes. Finding efficient microorganisms of biological control, to protect food, is the fourth challenge and a promising alternative to control undesirable organisms.Positioning Annonaceae as the Emblematic Fruit of Latin America in the International Markets operating a Continental Value Chain, and converge with all continental actors in this great effort imposed by the global dynamics, is undoubtedly the Grand Challenge and our invitation, to assume, in this memorable International Congress . As such is integration of Continental Ecosystem Innovation for Sustainable Development of the Annonaceae.

Index Terms: Annona muricata, Business Network, Value Chain, Market Drivers Factors, Climate Change, Carbon Footprint.
\end{abstract}

\footnotetext{
${ }^{11}$ Palestra Anonáceas - V Congresso Internacional \& Encontro Brasileiro sobre Annonaceae: do gene à exportação (19 a 23 de Agosto de 2013). Botucatu-SP.

2E-mail: joelsalas@yahoo.com
} 


\section{INTRODUCTION}

In a globalized agribusiness increasingly competitive, businesses that are tailored to meet the needs of consumers are the only ones to survive and grow. In a world that is changing supply chains for fruits and vegetables, it is not like before. The linear chains are being exchanged for networks with many agents and different scenarios, and the situation it is not always clear. That is why, when analyzing the current challenges of the Annonaceae World in Mexico, we take into account all stakeholders, from producers to target markets and to final consumption because in the future, food producers, processors, logistics service providers, and distributors, do not compete more as individual entities, but they collaborate on a "value strategic Chain", competing against other value chains on the market.

In Mexico there are 14 genera and 63 species of Annonaceae, the soursop being which has the highest level of production and market presence. (ANDREW AUGUSTINE J. 2011).

The Agricultural Information System and Fisheries SIAP recorded for closing soursop production for 2011, the following figures:

\begin{tabular}{|c|c|c|c|c|c|c|}
\hline Location & $\begin{array}{c}\text { Seeded } \\
\text { Area }(\mathrm{Ha})\end{array}$ & $\begin{array}{c}\text { Cropped Area } \\
\text { (Ha) }\end{array}$ & $\begin{array}{l}\text { Production } \\
\text { (Ton) }\end{array}$ & $\begin{array}{c}\text { Yield } \\
\text { (Ton/Ha) }\end{array}$ & $\begin{array}{l}\text { Sales } \\
\text { Price } \\
\text { (S/Ton) }\end{array}$ & $\begin{array}{l}\text { Production } \\
\text { Value } \\
\text { (Thousands } \\
\text { MXN) }\end{array}$ \\
\hline CAMPECHE & 14.50 & 14.50 & 72.61 & 5.01 & $7,100.00$ & 515.53 \\
\hline COLIMA & 214.70 & 196.70 & $2,078.27$ & 10.57 & $3,935.71$ & $8,179.47$ \\
\hline GUERRERO & 192.00 & 192.00 & $1,110.43$ & 5.78 & $3,528.36$ & $3,918.00$ \\
\hline JALISCO & 12.00 & 9.00 & 36.50 & 4.06 & $3,447.12$ & 125.82 \\
\hline MCHOACAN & 156.00 & 156.00 & 900.20 & 5.77 & $6,903.62$ & $6,214.64$ \\
\hline MORELOS & 38.00 & 18.00 & 229.06 & 12.73 & $8,591.29$ & $1,967.92$ \\
\hline NAYARIT & $1,631.85$ & $1,622.85$ & $14,960.18$ & 9.22 & $3,831.13$ & 57,31437 \\
\hline PUEBLA & 46.00 & 46.00 & 110.50 & 2.40 & $3,300.00$ & 364.65 \\
\hline TABASCO & 44.00 & 44.00 & 329.00 & 7.48 & $17,571.37$ & $5,780.98$ \\
\hline VERACRUZ & 27.00 & 10.00 & 44.80 & 4.48 & $8,000.00$ & 358.40 \\
\hline YUCATAN & 24.50 & 24.50 & 178.60 & 7.29 & $18,910.41$ & $3,377.40$ \\
\hline & $2,400.55$ & $2,333.55$ & $20,050.15$ & 8.59 & $4,394.84$ & $88,117.18$ \\
\hline
\end{tabular}

In these productive regions, the cultivation of guava cultivars developed in no more than 10 hectares, Cultivars representing this structure, little more than $90 \%$ of the surface. (LIBRADO VIDAL, 2012)

\section{METHOD}

We analyzed trends in international markets and the participation of stakeholders in the innovation systems of agrifood chains and the integration of value chains and new forms of market participation for sustainability and agribusiness competitiveness in the economy of knowledge.

\section{RESULTS AND DISCUSSION}

The integration of producers in a value chain demand Inter-entrepreneurial Cooperation, called by some "company-Red" or "Business Network", becoming basic and essential for the competitiveness of agribusiness. Company-Network is to create a 
small business into a large scale, to jointly exploit the advantages of large companies (consortia) and small business (speed) and the flexibility is achieved with more and more autonomy. This is the first challenge.

Dynamic markets, dynamic structures. It is now time to look at technological devices (TICs.) and refresher programs, the best way to share knowledge and promote in this way, the collective creation of organizational reality far from vertical own ideas of the industrial age.

The distinctive feature of the current technological revolution (CASTELLS, 1998) on the above it is not only the presence of knowledge and information, but the ability involved in the processing and dissemination of information and consequent increases in productivity and competitiveness of the actors, whether firms, regions and countries.

Telecommunications has established itself as a cross-cutting sector for economic apparatus complex. They are an essential input for people and businesses in their daily activities. In the network business model, the emphasis is on the internal organization and external actors in the production world and the results are measured by the competitiveness of the whole.

The knowledge society network drives as a specified organization, whose advantages are flexibility and adaptability, essential qualities to survive in a society shaken by changes (CASTELLS, 2001). Networks as sets of interconnected nodes retake a new importance with the driving force of the Internet, leaving the private sphere where they were confined to deploy its expertise in the coordination and management of complexity (CASTELLS, 2001).

Managing this complexity and heterogeneity influences individual behavior and collective social actors. Learning and innovation in an organization depends on the ability to mobilize tacit knowledge and encourage interaction with explicit knowledge. All organizations have a mixture of both knowledge, what makes them different is the relative importance of each of them (NONAKA, and TAKEUCHI, 1995), and his new role is to foster collective learning through networks.

According to studies Cimoli (2000), "International convergence requires that in the long run economies are able to transform their productive structure, from a growth pattern based on the income derived from the abundance of a factor of production to another based on the income generated by knowledge and learning. In these transformation knowledge diffusers sectors must reach a growing role in the industry. The effects of trawling sectors and their virtuous relationship with technology investment and external competitiveness are needed to combine the rapid productivity growth with high employment in the economy, reducing structural heterogeneity. In economies with little structural change, localized increases in productivity are of little help to reduce informality and heterogeneity ".

Factors (drivers) key markets, presented as second challenges are:

- Food Safety

- Product Quality

- Innovation

- Decreased Costs, and

- New Market Development

The food industry faces a significant slowdown in productivity growth, the "slowdown in spending growth and diversion of funds previously used to achieve improvements in agricultural productivity" (PARDLEY and ALSTON, 2010; STADS, 2011). In addition, there is a slowdown in investment in research, development and innovation, and in some countries even have seen a decline in investment levels (BEINTEMA, and STADS (2008); PARDLEY and ALSTON, 2010).

This trend of decline in investment in research and development impacts innovation in the food industry, in contrast to what was observed in the Twentieth Century (ALSTON, 2011) and has important implications for food security due to decreased productivity and competitiveness in general (STADS BEINTEMA, 2010).

In innovation management specifically in the Mexican system, different institutions function as intermediaries. These intermediaries have been called innovation managers. Courtney and Winch define an innovation manager as "an organization that is focused on the creation or implementation of innovation, but rather to make it possible for other institutions to innovate". In other words, innovation managers are institutions within an innovation system, which catalyze innovation from other participants in the system but without producing innovation themselves. Innovation managers have an important role; these dynamics introduce an element of the process connecting the actors, closing gaps in the system, optimizing interactions and improving productivity and innovation on farmers and small-scale producers. Innovation managers are facilitators and not directly involved in the development of innovation and technology; simply facilitate cooperation, articulate needs and network integration (KLERKS, HALL and LEEUWIS, 2009). 


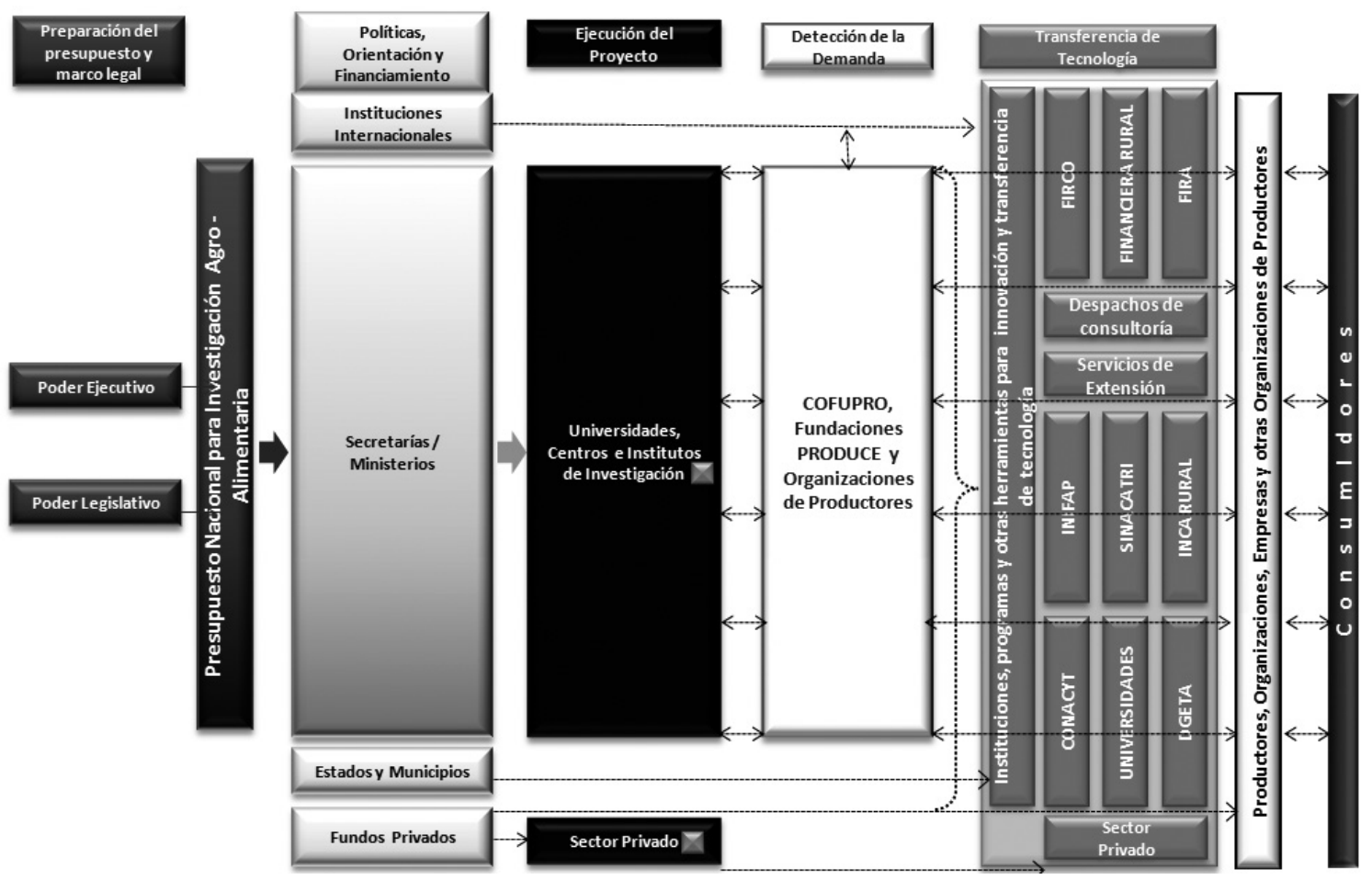

\section{The National Agricultural Innovation System in Mexico}

INNOVAGRO Network aims to promote the management of innovation processes in the food industry by sharing knowledge, experience, information, and cooperation, while taking advantage of all the synergies available among members. Specifically, the Network develops the following lines of action: strengthening skills and best practices through seminars, conferences and meetings between members, Technical Cooperation connectivity, efficient mechanisms that facilitate socialization, dialogue and process analysis, innovation management, construction of a bank of success stories.

In the Network Integration features the participation of the following actors:

- Private actors linked to food chains.

- Public and the National Institutes of Agrifood Innovation equivalents recognized as the leading technology providers and managers of innovation. Education

- Universities and Institutions of Higher

- Ministries and departments related to innovation processes and innovation management.

They are actors who play different roles and act at different levels, but through the Network establish multiple relationships and partnerships to enhance the innovation management processes and contribute to the solution of the problems of productivity, competitiveness, equity and sustainability of the agribusiness sector

Agricultural Innovation Systems generate interactive mechanisms to enhance institutional cooperation between different national and international actors. The best solution to overcome global problems of the food industry is the participation, cooperation and coordination through networks involving different actors of all countries whose agendas integrate between other aspects of logistics costs such as shipping, storage, transport and a non-acceptable, are powerful motives to organize more effective systems. Just as on the development of new markets that are by definition "niches" in terms of pro-biotic identity and functionality of the Annonaceae.

The new climate scenarios expected in the future will not only have implications for food production, but also in trade of them. Latin America - Amazon rain forest and the eastern and central 
southern Mexico and probably be gradually replaced by savannas. Parts of northeastern Brazil and most of central and northern Mexico are drier due to a combination of climate change and land use by man. For the 2050 s, $50 \%$ of agricultural lands are likely experiencing desertification and salinization.

North America - Climate change will constrain water resources, and exploited by the growing demand from agriculture, industry and cities. The rising temperatures will continue to fall snow cover in the mountains and increasing evaporation, which will alter the seasonal water availability. The reduction of water from the Great Lakes and major river systems affect water quality, navigation, recreation and hydropower. Wildfires and insect pests will continue to intensify in a warmer world with drier soils. During the century, basically are reordered ecosystems in North America also because the species bound by the pressures, migrate north and to higher elevations.

This is a third challenge. The competitive adaptation of the Annonaceae to climatic changes. It is foreseeable that some exporting areas can, for a process of adaptation to new climatic conditions, play a role somewhat weaker supplier. To stay competitive, every region of the world will find their best competitive advantages; the American continent has great potential for the future, in a world greatly impacted by climate change. There is a chance that this continent takes a leading role in the international food trade.

To position the Annonaceae as Latin American Flagship Fruit in international markets in Continental Value Chain, will be the Grand Challenge for Mexican Guanabanero World Actors. Converge with all the actors in this great effort Continental imposed global dynamics.

In other development challenges, the crop yields worldwide each year is reduced 20 to $40 \%$ due to pests and plant diseases, he warned the Ministry of International Plant Protection Convention (IPPC) of the Organization of United Nations Food and Agriculture Organization (FAO). "Today we live in a globalized and interconnected world incredibly full of opportunities for pests and diseases spreading from one country to another. Reduce risks and prevent or minimize this spread has much more effective cost than trying to eradicate or manage an outbreak after its appearance, "said Craig Fedchock, coordinator of the IPPC Secretariat. Though no exact available figures, it know that a significant number of pests in plants is introduced through global trade, the need for sustainable agriculture and to avoid the presence of chemical residues in food, as well as resistance of pathogens to artificial products have raised the need to develop alternative methods of control of these organisms, safer, effective and economical. The use of microorganisms to protect food is a challenge and a promising alternative to control undesirable organisms.

It is essential that biological control agents are adapted to the site that should exert its action. Therefore, the chances of finding efficient microorganisms are increased if they are looking in the same environment and the same fruit when they will be applied. It is therefore assumed as fourth challenge its application.

The carbon footprint created as a measure to quantify and generate an indicator of the impact of an activity or process has on climate change, beyond the big emitters. This represents a measure of the organization contribution to be socially responsible entities and an element of awareness for the assumption among citizens of more sustainable practices.

It is also an excellent tool for differentiation to consumers, and government customers increasingly demanding with regard to the need to minimize the environmental impact of business activities. So the carbon-footprint is already an effective strategy to anticipate the needs of your customers, thus helping to consolidate the image of business and to be prepared for possible future regulatory requirements. All these resulting in a fifth challenge application.

\section{CONCLUSIONS}

The use of foresight, understood as future building is an ongoing activity that can generate future images of high quality (anticipation), encourage participation and assimilation of scenarios and future challenges (ownership), the implementation of relevant projects (action) and the constant feedback facilitating examining the gaps between the images of future proposals and achieving goals in this (learning) is a relevant tool for actors in the Annonaceae world, managed by its value chain.

With increasing globalization, the geographic shift of growth, trade and investment, technological advances, the rise of global value chains, the proliferation of preferential trade agreements and the growing influence of non-tariff measures, the world Latin of the Annonaceae, must Integrate a Great Value Chain and adopt a new approach to managing their competitiveness and sustainability in markets; caring reciprocity and flexibility to fully take into account the realities and needs of some Members of different levels of development, and to 
integrate a more dynamic process leading gradually towards convergence, in order to meet the challenges of sustainability.

To position the Annonaceae Fruit as emblematic of Latin America in the International Market Value Chain operating as Continental, and converge with all actors in this great continental effort imposed by global dynamics, it is undoubtedly the Grand Challenge and our invitation, to assume, in this memorable International Congress. Just as the Continental Ecosystem Integration Innovation for Sustainable Dekelopentofthe Annonaceae.

ALPUCHE-SILVESTRE, E.; GARCÍA-AGUILAR, L.; BOLIVAR FERNÁNDEZ, N. Aprovechamiento integral de la guanábana (Annona muricata L.). In: CONGRESO NACIONAL DE Annonaceae, 3., 2006., Villahermosa. Memoria... p.58

ALVAREZ, C. O.; NESKE, A. ; POPICH, S.; BARDON, A. Toxic effects of annonaceous acetogenins from Annona cherimola on Spodoptera frugiperda (Lepidoptera: Noctuidae). Journal of Pest Science, Heidelberg, v.80, p.63-67, 2007.

ANDRES-AGUSTIN, J. El cultivo de chirimoya (Annona cherimola Mill.) en el estado de Michoacán, México. Proceedings of Interamerican Society for Tropical Horticulture, Guatemala, v.41, p.152-161, 1997

ANDRÉS-AGUSTÍN, J.; ANDRÉS-HERNÁNDEZ, L. Biología, diversidad, conservación y uso sostenible de los recursos genéticos de Annonaceae en México. Chapingo: Universidad Autónoma Chapingo, 2011. $141 \mathrm{pp}$

ANDRES-AGUSTIN, J.; GONZALEZ-ANDRES, F.; NIETO-ANGEL, R.; BARRIENTOS-PRIEGO, A.F. Morphometry of the organs of cherimoya (Annona Cherimola Mill.) and analysis of fruit parameters for the characterization of cultivars, and Mexican germoplasm selections. Scientia Horticulturae, Amsterdam, v.107, p. 337-346, 2006.

ANGIOSPERM PHYLOGENY GROUP. An ordinal classification for the families of flowering plants. Annals of the Missouri Botanical Garden, Saint Louis, v.85, p.531-553, 1998.

CHATrou, L. W. The Annonaceae and the Annonaceae Project: a brief overview of the state of affairs. Acta Horticulturae, The Hague, n.497, p. 43-49, 1999.
FARRERA-SARMIENTO,O. Aspectos etnobotánicas de anonáceas en Chipas, México. In: GONZÁLEZ-ESQUINCA, A.R.; MERCEDESCAZARES, L.; GUTIÉRREZ-JIMÉNEZ, J.; SCHLIE-GUZMÁN, M.A.; VIDAL-LÓPEZ, D.G. (Coord.). Anonaceas: plantas antiguas, estudios recientes. Tuxtla: Universidad de Ciencias y Artes de Chiapas, 2011. p.121-128.

GEORGE, A.P.; NISSEN, R. J. Propagation of Annona species. Scientia Horticulturae, Amsterdam, v.33, p.75-85, 1987.

GONZÁLEZ G. J.; GUZMÁN G.S.; MICHEL R.A.; RADILLO, J.R.; BAZAN T. M.; CERVANTES T.F. Evaluation of pregerminative treatmentsin Soursop (Annona muricata L.) Seeds HortScience, Alexandria, v.40, p.1023, 2005.

GONZÁLEZ G.J.M.; RADILLO, J.F.; BAZAN T.M.; GONZÁLEZ R.J.C. Evaluation of three grafting methods for propagating soursop (Annona muricata $\mathbf{L}$.) in the dry tropic region of Mexico. HortScience, Alenxadria, v.40, p.1082, 2005.

PADJAMA, V.; THANKAMANY, V.; HISHAM, A. Antibacterial, antifungal and antihelmintic activities of root barks of Uvaria hooki and Uvaria narum. Journal of Etnopharmacology, Lausanne, v.40, p.181-186, 2005.

PINTO, A. C. DE Q.; CORDEIRO, M.C.R.; ANDRADE, S. R. M. DE; FERREIRA, F. R.; FILGUEIRAS, H. A. DE C.; ALVES, R. E.; KINPARA, D. I. Annona species. Southampton: International Centre for Underutilised Crops, 2005.

SEGURA, L.S.; ANDRES, J. Where do we go with Annona in Mexico?. In: INTERNATIONAL SYMPOSIUM ON WILD RELATIVES OF SUBTROPICAL AND TEMPERATE FRUIT AND NUT CROPS, 1., 2011. Davis. Proceedings...

SEGURA, S.; LEFEVRE, C.; CARMONA, A.; MARROQUÍN, L. Underutilization of the genetic resources of Annona diversifolia Saff. in the communities of Tierra Caliente, México. In: SIMPOSIO INTERNACIONAL DE RECURSOS GENÉTICOS DE AMÉRICA LATINA Y EL CARIBE, 8., 2011, Quito. Proceedings... 